\title{
Kinesic Components of Terrorist Nonverbal Behavior
}

\author{
Andrei G. Fomin and Elizaveta A. Mona* \\ Kemerovo State University \\ 6 Krasnaia Str., Kemerovo, 650043 Russia
}

Received 14.09.2016, received in revised form 26.09.2016, accepted 10.01.2017

\begin{abstract}
There is no general understanding of correlation between verbal and nonverbal components in communication process at the current stage of both domestic and foreign linguistics development. However, most of the researchers believe that nonverbal organization of an individual's speech plays a significant role in presenting the informative content of an utterance. One of the key elements of nonverbal communication is kinesics, elements of which form a visual semiotic system. In this regard, the aim of this study is to examine kinesic components of terrorist nonverbal behavior - on the material of 8 Islamic State militants' video messages, selected by continuous sampling, we attempt to analyze the peculiarities of facial gesture, gesticulation, pantomimicry and eye contact established by the speaker. The results of the research show that despite the informative value of kinesic components of an individual's nonverbal behavior, only the complex of nonverbal and verbal means, decoded simultaneously, is efficient enough to effectuate the speaker's pragmatic intention.
\end{abstract}

Keywords: nonverbal behavior, kinesics, facial gesture, gesticulation, pantomimicry.

DOI: 10.17516/1997-1370-0040.

Research area: philology.

\section{Introduction}

Since nonverbal speech organization is not considered a linguistic category, it attracted Russian linguists only in the end of the 1990s, while the first attempts to study this aspect of communication abroad were made in 1960-70s. Thus, American psychologist A. Mehrabian noted that information is conveyed through verbal means (words) only by $7 \%$, through sound (including the voice tone and intonation) - by $38 \%$ and trough nonverbal means - by $55 \%$. Professor R. Birdwhistell obtained analogous results - according to his research, verbal description in the process of communication amounts to $35 \%$, while $65 \%$ of information is perceived through nonverbal means (Pease, 1984). Therefore, it is possible to conclude that nonverbal signs predetermine both the process of communication and its outcome, surpassing verbal signs in informative value.

Likewise, V.I. Shakhovskii supposes that nonverbal semiotic system is prior. The scholar also emphasizes that it "surpasses the secondary (verbal) in its reliability, speed, straightforwardness, candidness and the quality (power) of emotional expression and

(C) Siberian Federal University. All rights reserved

* Corresponding author E-mail address: andfomin67@mail.ru; elizaveta-mona@yandex.ru 
communication, as well as in adequacy of its decoding by the recipient» (Shakhovskii, 2009: 33). E.A. Vansiatsaia supports this idea, adding that «the verbal part of an utterance overlays the already expressed nonverbal one» (Vansiatskaia, 1999: 51).

At the same time, correlation between verbal and nonverbal components in communication is dubious. A.A. Reformatskii claims that verbal and nonverbal communicative systems do not overlay each other but rather co-exist in a complex correspondence, since their constituents can complement, replace or even contradict each other. Hence, the majority of Russian and foreign scholars deem it advisable to perceive nonverbal communication as a competent information channel. However, nonverbal aspect of an individual's communicational behavior (alongside with the issue of correlation between nonverbal language codes and natural language) has not been systematically described or even touched upon in some respects yet (Kreidlin, 2002: 6). That is why studying the phenomenon of nonverbal communication should be considered one of the most important directions of modern linguistics.

\section{Theoretical framework}

In a broad sense, nonverbal communication in linguistics is understood as «communication without words through a variety of communication channels» (Ting-Toomey, 1999: 200). Due to the possibility of using different channels of transferring information, nonverbal communication is usually understood as including the following subtypes: proxemics, sensorics, chronemics and kinesics, the elements of which (eye contact, facial expressions, gestures and posture) form one of the first visual semiotic systems adopted in ontogeny.

The article closely examines kinesics, the «visually perceived range of movements performing the expressive-regulatory function in communication» (Dmitrieva, 2001: 200). Kinesics includes:

- expressive movements, manifested in facial expression and gestures;

- pantomimicry (motility of the whole body based on pose, pace and posture);

- eye contact.

\section{Statement of the problem}

The necessity of examining the kinesic aspect of communicative act in detail is determined by the fact that modern mass media tends to involve the visual channel of communication in presenting the verbal message with increasing frequency. Consequently, the information received by the recipient becomes a complex entity, correct and complete interpretation of which is possible only if all of its components are analyzed.

In this research, which is aimed at studying terrorist communicative behavior (on the material of Islamic State militants' video messages), we attempt to analyze and interpret some elements of the speakers' nonverbal behavior in order to fully comprehend their intentions. It is presupposed that nonverbal organization of terrorist speech vastly contributes to effectuation of the speaker's pragmatic intention (intimidating the target audience). To confirm this hypothesis we analyzed 8 video recordings, lasting from 1 minute 20 seconds to 6 minutes 11 seconds and examined the terrorists' facial gesture, gesticulation and pantomimicry changes, as well as peculiarities of eye contact, maintained by the speaker during the filming of a video message.

\section{Discussion}

It is noteworthy that in order to ensure personal safety, terrorists intentionally conceal faces with black masks or pieces of cloth. As such, it is sometimes impossible to keep track of their facial expression changes during the 
video message. Moreover, according to modern research «static or invisible face of an interlocutor causes loss of information by 10-15\%» (Fesenko: 95). This was indicated in 3 (40\%) video messages. Although, the speaker's face was not covered in the remaining $5(60 \%)$. The analysis of this material made it possible to reach several conclusions connected with the peculiarities of terrorist facial gesture.

It was noted that the prevailing emotion expressed by the speaker is anger. The terrorist's facial expression remains practically unchanged during the whole message; in every video (where the terrorist's face is not concealed) the audience is able to see knit or lowered eyebrows, stiff lips, clamping tightly when there is a pause in speech. The chin muscles are in an elevated tone and open mouth takes on a rectangular shape, with much exposed teeth, indicating hostile attitude of the speaker. This conclusion is also confirmed in P. Ekman's study (Ekman: 117-119).

In some fragments of the analyzed video messages, the speaker's facial expression conveys the emotion of disgust, as indicated by the following signals: puckered nose, frowning eyebrows, raised upper lip. It is important that such a facial expression appears when the terrorist reprobates another religious philosophy («How can you remain, living amongst the disbelievers, under their unjust manmade laws...»). It is also noted when political leaders are being criticized («Your leaders, those men and women whom you have elected to represent yourselves in the running of your country's affairs, have gone far out of their way...»).

The analysis of the video messages showed the terrorists' intention to deprecate and insult the recipient, as well as high degree of their annoyance (which often provokes sudden outbursts of anger). It is reflected by the speaker's facial gesture (facial muscles become extremely tense) and verbal presentation peculiarities (speech tempo becomes uneven, timbre rises). It is important to note the following: according to psychologists, the aforementioned factors indicate the individual's readiness to act aggressively (Radchenko: 64), which definitely contributes to the intimidation of the recipient.

The produced effect is also increased by the fairly active gesticulation. The research showed that among the gestures, employed by the terrorist during the speech, there are mostly communicative (gestures of attracting attention, negative and interrogatory gestures) and modal ones, expressing the speaker's attitude (mostly of unsatisfaction).

In order to attract the attention of the audience to the most important part of the speech, the terrorist points abruptly towards the camera (in 4 analyzed videos out of 8) ( If you are a real man, you will send all your forces down...»), as if talking directly to the viewer. The terrorist disapprovingly shakes his head in some speech fragments that contain reproach («They thought that they were going to defeat the Muslims...»). Threats are supported by dynamic lunges towards the camera, waving a fist («We will let your children and your elderly cry, the same as we did in Yarmouk...») and even by showing the weapon in some cases («We will not stop and we will keep on fighting. And we will fight you and we will defeat you!»).

In this regard, the role of pantomimicry is also of great importance, since any change of it occurs spontaneously, being the direct reflection of the speaker's emotional state. It was noted that in all video recordings observed the speaker does not move around the filming area; during the whole speech he either stands or sits still. Irrespective of that, the terrorist has his shoulders widely straightened, the posture is always straight and the head is raised. According to psychologists, such a body position shows that an individual is confident (Glass: 67). This is also 
proved by the continuous eye contact, observed in all 8 video messages. During the whole speech the terrorist looks directly into the camera, without taking his eyes off of it. It is remarkable, that in 5 video messages $(62,5 \%)$ there were 2 cameras involved in filming. Using an additional camera, which the speaker does not look into, can be explained by the terrorists' intention to draw the recipient's attention to the surroundings, mostly consisting of ruined buildings and a large amount of military equipment, weaponry. Thus, we can conclude that the terrorists intentionally employ the visual communication channel to intimidate the audience.

However, it would be inaccurate to claim that the speaker's nonverbal behavior is planned beforehand. Except for the eye contact, all the kinesic components (in the framework of the analyzed material) are mostly spontaneous. This is proved by the fact that active gesticulation and changes in facial gesture are present not only in the main text of the speech but also during the vocalized pauses and moments when phonation stops (this aspect is vital as while analyzing behavior, either verbal or nonverbal, it is necessary to consider that it is composed of acts of both action an inaction) (Shevchenko: 113).

\section{Conclusion}

The results obtained during the analysis of some paralinguistic peculiarities of terrorist speech organization, undoubtedly, support the importance of nonverbal aspect of communication. The complex of kinesic components forms an independent informational channel, the presence of which, however, does not exclude the necessity of presenting the verbal message. In other words, we support the idea of A.A. Reformatskii who states that verbal and nonverbal communication systems exist as parallel channels and it is not reasonable to compare their importance since only the unity of verbal and nonverbal signs allows to fully convey the informative intention. So, during the analysis of terrorists' gestures, pantomimicry, facial gesture and peculiarities of establishing eye contact, it was noted that even though these aspects of communication have an independent informative value, their thorough examination is possible only due to the presence of the verbal message. Only the complex of verbal and kinesic means, decoded simultaneously, is effective enough for the speaker to perform his pragmatic intention, which in the framework of the analyzed material meant intimidating the target audience.

\section{References}

Dmitrieva, Iu.V. (2011). Osobennosti verbal'nogo vyrazhenia mimiki i zhestov v angliiskom, nemetskom i russkom iazykakh [Peculiarities of Verbal Representation of Mimics and Gestures in English, German and Russian Languages], In Vestnik CHGPU, 8, 200-210.

Ekman, P., Frizen, U. (2010). Unmasking the Face: A Guide to Recognizing Emotions from Facial Expressions. Cambridge, Malor Books, 272 p.

Fesenko, O.P. (2015). Akademicheskaia ritorika [Academic Rhetorics]. Omsk, ANO VPO “Omskii ekonomicheskii institut", 329 p.

Glass, L. (2003). Ia chitaiu vashi mysli [I Know What You're Thinking]: per. s angliiskogo E.M. Pesterevoi. AST: ZAO NPP Ermak, 251 p.

Kreidlin, G.E. (2002). Neverbal'naia semiotika: Iazyk tela i estestvennyi iazyk [Nonverbal Semiotics: Body Language and Natural Language]. Moscow, Novoe literaturnoe obozrenie, 592 p.

Pease, A. (1984). Body Language. Sheldon Press, 148 p. 
Radchenko, O.A. (2009). Issledovanie agressivnogo diskursa [The Study of an Aggressive Discourse], In Vestnik MGPU. 1(3), 60-66.

Shakhovskii, V.I. (2009). Emotsii kak ob"ect issledovaniia v lingvistike [Emotions as the Object of Linguistic Study]. Voprosy psikholingvistiki, 9, 29-43.

Shevchenko, I.S. (2014). Kontsepty kommunikativnogo povedeniia v kognitivno-diskursivnoi paradigme [Concepts of Communicative Behavior in Cognitive Discursive Paradigm], In Vestnik $M G P U, 1,110-120$.

Ting-Toomey, S. (1999). Communicating across Cultures. New York: Guilford Press, 310 p.

Vansiatskaia, E.A. (1999). Rol' neverbal'nykh $i$ verbal'nykh komponentov kommunikatsii $v$ tekstakh, otrazhaiuschikh emotsional'nye reaktsii cheloveka, $i$ ikh sootnoshenie [The Role of Nonverbal and Verbal Communication Components in Texts, Reflecting Human Emotional Reactions, and Their Correlation]. Ivanovo, $161 \mathrm{p}$.

\title{
Кинесический аспект \\ невербального поведения террориста
}

\author{
А.Г. Фомин, Е.А. Мона \\ Кемеровский государственный университет \\ Россия, 650043, Кемерово, ул. Красная, 6
}

\begin{abstract}
На настоящем этапе развития науки о языке в трудах отечественных и зарубежных ученых нет общего представления о характере соотношения вербальных и невербальных компонентов в процессе коммуникачии. Тем не менее исследователи едины во мнении, что невербальная организация речи индивида несет значимую роль в презентации информационной содержательности высказывания. Одним из важнейших элементов невербальной коммуникации является кинесика, элементь которой формируют визуальную знаковую систему. В связи с этим целью данного научного исследования является рассмотрение кинесического аспекта невербального поведения террорриста: на материале 8 видеообращений боевиков ИГИЛ, отобранных методом сплошной выборки, предпринимается попытка анализа мимики, жестикуляции, пантомимики и особенностей визуального контакта, устанавливаемого спикером при выступлении. Полученные в ходе исследования результаты позволили заключить, что, несмотря на самостоятельную информативную содержательность кинесических особенностей невербального поведения индивида, лишь совокупность невербальных и вербальных средств, декодируемых одновременно, обладает необходимой эффективностью в реализаиии его прагматической установки.
\end{abstract}

Ключевые слова: невербальное поведение, кинесика, мимика, жестикуляция, пантомимика.

Научная специальность: 10.00.00 - филологические науки. 